Productivity Changes and Intangible Assets : Evidence from French Plants

Corinne Autant-Bernard, Jean-Pascal Guironnet, Nadine Massard

Mars 2010 


\section{GATE Groupe d'Analyse et de Théorie Économique Lyon-St Étienne}

93, chemin des Mouilles 69130 Ecully - France

Tel. +33(0)4 72866060

Fax $+33(0) 472866090$

6, rue Basse des Rives 42023 Saint-Etienne cedex 02 - France

Tel. +33 (0)4 77421960

Fax. $+33(0) 477421950$

Messagerie électronique / Email : gate@gate.cnrs.fr

Téléchargement / Download : http://www.gate.cnrs.fr - Publications / Working Papers 


\title{
Productivity Changes and Intangible Assets: Evidences from French Plants
}

\author{
Corinne AutANT-BERnARD ${ }^{*}$, Jean-Pascal GuIRONNET ${ }^{* *}$ and Nadine MASSARD ${ }^{* * *}$
}

\begin{abstract}
This paper investigates the effect of inter-firm and intra-firm spillovers on the productivity of firms, using French data. The Luenberger Productivity Indicator (LPI) is used to estimate the productivity and to break it down into several components (e.g. efficiency, biased technical progress, scale effects, etc.). Using this approach, negative productivity changes are found due to the unfavourable economic situation over 2000-2002. Intangible assets underlying productivity change are then investigated through a Maximum Likelihood Random Effect (MLRE) model. Spillover effects - influencing Total Factor Productivity (TFP) and its correspondent components, technological and efficiency changes - are found.
\end{abstract}

Keywords: Productivity Change, Luenberger Indicator, Knowledge Externalities.

JEL-Classification: C31, C23, R11, R12.

\section{Acknowledgments:}

This paper has benefited from the discussions and financial support associated to the programme Intangible Assets and Regional Economic Growth. ECSC - ECSC RTD Programme. FP7-SSH-2007-1 (216813). European Commission.

The authors are grateful for the useful comments of Nicolas Peypoch.

\footnotetext{
This study was conducted within the framework of the European IAREG (Intangible Assets and Regional Economic Growth) contract and therefore received European subsidies.

*Université de Lyon, Université Jean Monnet, F - 42023 Saint-Etienne, France.

CNRS, GATE Lyon-St Etienne, UMR n 5824, 69130 Ecully, France

e-mail: corinne.autant@univ-st-etienne.fr.

** Université de Lyon, Université Jean Monnet, F - 42023 Saint-Etienne, France.

CNRS, GATE Lyon-St Etienne, UMR n 5824, 69130 Ecully, France

e-mail: jean.pascal.guironnet@univ-st-etienne.fr.

**** Université de Lyon, Université Jean Monnet, F - 42023 Saint-Etienne, France.

CNRS, GATE Lyon-St Etienne, UMR n 5824, 69130 Ecully, France

e-mail: nadine.massard@univ-st-etienne.fr.
} 


\section{Introduction}

The purpose of this article is to measure productivity changes and to investigate the role of intangible assets, in particular agglomeration forces and knowledge externalities, on the productivity performances of plants, using a sample of French firms over the period 20002002. As R\&D has been considered an important engine of economic growth and welfare (Romer, 1986), the measurement of the correspondent externalities is an interesting topic. Even though this evidence has been recognised for a long time at the macro-economic level, recent works investigate these intangible assets from a micro-economic viewpoint (e.g. O'Mahony and Vecchi, 2009). In the same vein, the main contribution of this paper is to analyse the impact of local spillover effects - in particular those due to R\&D investments - on plants' performances. The paper then proposes to give some answers to the following questions: Does the implementation of "high-performance" area ensure better plant performances? Does regional knowledge accumulation produce positive externalities for firms? Do firm intangible assets influence plant productivity?

Consequently, the first step of our study is an estimation of productivity. Plants' performances are calculated with a Luenberger Productivity Indicator (LPI), which has a more generalized form than the often-used Malmquist productivity index. Thus, LPI can be broken down into several components: technological efficiency, scale effect, pure efficiency and biased technological changes. Such an analysis is interesting as different forms of externalities can be grasped within each of these components.

In a second step, spillover effects are investigated through a MLRE model. The inclusion of spatial factors in our econometric estimations may show the productivity benefits of clustering effects and not only those attributable to the hypothetical linear process directly linking inputs to outputs (Yang et al. 2009). Finally, this framework improves upon previous research in three ways: $(i)$ by applying this approach to the spatial innovation topic, (ii) by investigating "non-neutral" technological progress, (iii) by simultaneously assessing "between" and "within" spillovers including both inter and intra-firm knowledge flows among plants. Following this approach, we found that intra-firms spillovers are highly significant as the human capital of the firms appears as a major determinant of each plant's productivity. Concerning inter-firms spillovers, we found that local R\&D investments of other industries improve technological component of productivity in "non-neutral" way whereas R\&D 
investments in the neighbouring departments have the opposite effect, thereby revealing "shadow effects".

This article is structured as follows. Section \#2 briefly discusses the studies closely related to this work. Section \#3 presents the mathematical program used to estimate productivity and the econometric model used to assess the role of intangible assets. Section \#4 presents the data and variables while section \#5 discusses the results. Section \#6 provides the concluding comments and policy implications derived from our results.

\section{Related literature}

Agglomeration forces were first investigated by Alfred Marshall (1980) who has identified the main sources of agglomeration externalities. Among them, three types of externalities can be distinguished: $(i)$ forward-backward linkage externalities stemming from non-adequate input prices; (ii) other pecuniary externalities issuing from the labour market and contributing to higher productivity of workers within agglomerations. More recently the literature has distinguished: Marshall-Arrow-Romer externalities resulting from a pool of specialized workers (Romer, 1986) and Jacob externalities resulting from a pool of diversified workers from various sectors of activity (Jacobs, 1969); (iii) knowledge externalities where industrial clusters facilitate information exchanges (Arrow, 1962; Cohen and Levinthal, 1989) and knowledge diffusion (via worker exchanges, for example). The two first are externalities rising from production activities whereas the last one involves R\&D activities.

Beyond the initial contribution of Marshall to the analysis of local externalities, new perspectives have recently appeared which highlight the negative role of some new forms of local externalities such as the congestion of transportation networks or pollution. In this contribution however, we concentrate our analysis on the positive impact of agglomerating activities knowing that this impact could sometimes be reduced by the existence of a negative side of agglomeration.

Since the contribution of Marshall, some recent theoretical frameworks have also been able to combine traditional agglomeration forces and knowledge externalities within location and growth models (Martin and Ottaviano, 1999). It is true that whilst on the one hand Krugman (1991) refers back to only two of the agglomeration forces suggested by Marshall: pecuniary externalities linked to the forward-backward linkages within industries and the role of labour market, ignoring the knowledge externalities which he considered to be unmeasurable and therefore intangible, on the other hand the theories of endogenous growth 
insist on the role of innovation and externality processes linked to the diffusion of knowledge within growth dynamics.

Finally, the "economic geography-endogenous growth" synthesis approaches unite these two perspectives giving a formalised framework for the analysis of localised growth dynamics based on innovation.

From an empirical viewpoint, two types of interaction have been addressed: $(i)$ the effects of local industrial structures upon performances in terms of employment (e.g. Henderson et al. 1995) or in terms of productivity (Henderson, 2003); (ii) the effect of knowledge externalities upon innovative performances (e.g. Audretsch and Feldman, 1999). By extension, our paper proposes to study simultaneously these two phenomena. Furthermore, whereas most of this literature uses aggregated data at different geographical levels, individual data at the plant level is used in this paper.

The present framework therefore, mainly investigates $R \& D$ externalities and agglomeration forces across space. Jaffe was the first economist to estimate R\&D spillovers on innovation. Using a knowledge production function, an effect of "local" pooling of R\&D on the patent productivity of a firm was found: research efforts of other firms may allow a given firm to achieve the same outputs with less research effort (Jaffe, 1986). Several studies have explored this topic (e.g. Jaffe et al. 1993). In particular, some frameworks have revealed a strongly positive relationship between a firm's innovativeness and its regional location (e.g. Beaudry and Breschi, 2003).

Our approach - estimating TFP as a first step and regressing it over spatial characteristics as a second step - is quite similar to the study by Black and Lynch (2001) and O'Mahonny and Vecchi (2009). In these papers however, TFP is computed from residuals of a production function whereas in our case TFP is estimated by LPI which allows us to break down the TFP into different components and take cyclical effects into account (see next section). Only similar analyses have been used in another field: for example, energy (Nakano and Managi, 2008) and ecologic economics (Jena and Managi, 2008). Our paper also extends these previous researches by investigating "non-neutral" technical progress. 


\section{Models}

In the following section, the mathematical program to compute LPI is first described and then the estimated production function is discussed.

\subsection{Measurement of Productivity}

This study applies directional distance function which is the dual to the profit function ${ }^{1}$ and the LPI. It does not require the choice of either input or output orientation (Chamber, 1996), by opposition to the Malmquist index.

In this framework, we use a non parametric approach - inspired of Data Envelopment Analysis (DEA) - with one output. Therefore, the production possibility set $T_{t}$ represents all feasible input $\left(x=\left[x_{1}, \ldots, x_{n}\right] \in \Re_{+}^{n}\right)$ and output $(y)$ vectors valid for a given time period $t$. It is defined as follows:

$$
T_{t}=\left\{\left(x_{t}, y_{t}\right) \in \Re_{+}^{n+1}: x_{t} \text { can produce } y_{t}\right\}
$$

In the remainder, technology obeys the traditional axioms (e.g. no production with no input, etc.). ${ }^{2}$

The proportional directional distance function - in a fixed direction $g=(h, k)-$ is defined as follows (Chambers et al. 1998):

$$
\begin{cases}D_{t}\left(x_{t}, y_{t} ; g\right)=\sup \left\{\delta ; x_{t}-\delta h, y_{t}+\delta k \in T_{t}\right\} & \begin{array}{l}
\left(x_{t}-\delta h ; y_{t}+\delta k\right) \in T_{t}, \delta \in R \\
-\infty
\end{array} \\
\text { otherwise }\end{cases}
$$

where $\delta$ is the maximal amount that $y_{t}$ can be expanded and $x_{t}$ can be reduced simultaneously given the technology $T_{t} . D_{t}(. ; g)$ is assumed concave and continuous on the interior $\mathfrak{R}_{+}^{n+1}$. The directional distance function is a representation of the technology $\left(x_{t}, y_{t}\right) \in T_{t} \Leftrightarrow D_{t}(x, y ; g) \geq 0$.

\footnotetext{
${ }^{1}$ See Briec, et al. (2006) for an analysis in a temporal framework.

${ }^{2}$ See Guironnet and Peypoch (2007) for a complete description.
} 
The linear programming calculates the LPI under Variable Returns-to-Scale (VRS) by solving the following optimization problem (Chambers et al. 1996):

$$
\begin{gathered}
D_{t}\left(x_{t}, y_{t} ; g\right)=\max _{\delta, \theta} \delta \\
\text { s.t. } \sum_{i} \theta_{i} y_{t}^{i} \geq \delta_{t} k+y_{t}^{i} \\
\sum_{i} \theta_{i} x_{t}^{i} \leq-\delta_{t} h+x_{t}^{i} \\
\sum_{i} \theta_{i}=1 \\
\theta_{i} \geq 0, \delta_{t} \geq 0 .
\end{gathered}
$$

where $\delta$ is the measure of inefficiency for firm $i$ in year $t$. The constraint $\sum_{i} \theta_{i}=1$ represents the VRS.

Then, LPI and the directional distance function are used (e.g. Barros and Peypoch, 2008) to measure the Total Factor Productivity (TFP) of a firm $i$ :

$$
\Delta T F P=\frac{1}{2}\left[D_{t}\left(x_{t}, y_{t} ; g\right)-D_{t}\left(x_{t+1}, y_{t+1} ; g\right)\right]+\left[D_{t+1}\left(x_{t}, y_{t} ; g\right)-D_{t+1}\left(x_{t+1}, y_{t+1} ; g\right)\right]
$$

This indicator can be decomposed into two components as follows (Chambers, 1996):

$$
\begin{aligned}
& \Delta T F P=\left[D_{t}\left(x_{t}, y_{t} ; g\right)-D_{t+1}\left(x_{t+1}, y_{t+1} ; g\right)\right] \\
& +\frac{1}{2}\left\{\left[D_{t+1}\left(x_{t+1}, y_{t+1} ; g\right)-D_{t}\left(x_{t+1}, y_{t+1} ; g\right)\right]+\left[D_{t+1}\left(x_{t}, y_{t} ; g\right)-D_{t}\left(x_{t}, y_{t} ; g\right)\right]\right\}
\end{aligned}
$$

where the term in the first brackets measures Efficiency Change $(\triangle \mathrm{EF})$ between period $t$ and $t+l$ while the arithmetic mean of the two last differences (inside the second brackets) captures a Technological Change $(\triangle \mathrm{TECH})$ component. $\triangle \mathrm{TECH}$ measures shift in the production frontier while $\triangle \mathrm{EF}$ measures changes in the position of a production unit relative to the frontier (Färe et al. 1994).

Furthermore, efficiency change can be broken down into two components, namely: Scale Effect (SE) and Pure Efficiency (PE) changes. For this purpose, the linear program is also used in assuming Constant Returns to Scale (CRS), by adding the constraint $\theta_{i} \geq 0$ instead 
of VRS (i.e. $\sum_{i} \theta_{i}=1$ ). SE is then the difference between overall technical efficiency (under CRS) and PE (under VRS).

Finally, input-neutral technical change as introduced by Briec et al. (2006) requires the input set to be representable as a translation in the direction of $h$ of an input set that is independent of the state of technology. The Input Biased (IB) technical change is defined by:

$$
\Delta I B=\frac{1}{2}\left\{\left[D_{t+1}\left(x_{t}, y_{t} ; g\right)-D_{t}\left(x_{t}, y_{t} ; g\right)\right]+\left[D_{t}\left(x_{t+1}, y_{t} ; g\right)-D_{t+1}\left(x_{t+1}, y_{t} ; g\right)\right]\right\}
$$

Holding the output vector constant at $y_{t}$, IB is the arithmetic mean of the technical change in a direction $g$ with respect to $x_{t+1}$ and $x_{t}$. By opposition, Magnitude of Technological (MT) change is defined by:

$$
\Delta M T=D_{t}\left(x_{t}, y_{t} ; g\right)-D_{t+1}\left(x_{t}, y_{t} ; g\right)
$$

Technological decomposition can therefore be expressed by $\triangle \mathrm{TECH}=\Delta \mathrm{IB}+\Delta \mathrm{MT}$. Technology is Hicks neutral whenever the marginal rate of substitution between inputs is unaffected by technological change, corresponding to "homothetic shift" in the isoquants. Hence, biased technological change tends to influence the relative contribution of each input to the production process. Thus, technological change is input parallel neutral only if technology exhibits graph translation homotheticity $(\triangle \mathrm{IB}=0 ;$ Briec and Peypoch, 2007).

To calculate the resource directional distance functions, we define $g=(h, k)=(x, y)$. This measurement is thus linked with the proportional distance function (Briec, 1997). LPI is applied to each industry, where each plant's Added Value per worker (AV) is explained by its own characteristics, i.e. the following four inputs: Capital per worker (K); Human Capital indicator (HC), i.e. number of individuals employed in $\mathrm{R} \& \mathrm{D}$ divided by total number of workers; R\&D Investments per worker (RDI); Wage Means of the workers in the plant (WM). WM can also be interpreted as a qualitative proxy of human capital (i.e. indicator of schooling and learning by doing, etc.). 


\subsection{Measurement of Spillovers}

This section presents econometric models for examining the relationship between intangible assets and the productivity performances of plants. The estimation of spatial externalities is based upon a production function (Griliches, 1979). The productivity change of a firm $i$ is represented by a Cobb-Douglas function:

$$
\Delta P C_{i t}=\left(\Delta E_{i, t-1}\right)^{\beta 1}\left(\Delta R D_{i, t-1}\right)^{\beta 2}
$$

where $\triangle P C_{i t}$ is the annual Productivity Change (such as the above defined TFP, TC, EC, SE, $\mathrm{PE}, \mathrm{IB}$ and MT) for a plant $i$ at time $t-1 ; E_{i}$ is a set of spatial variables which take pecuniary externalities from industrial clustering into account (see table \#1). Furthermore, in order to introduce knowledge externalities, some other proxies are added at different spatial levels (Acs et al. 1991; Autant-Bernard, 2001a; Bottazi and Peri, 2003), namely: $R D_{i}$ the change in the research inputs within the area (see next section for more details on the construction of variables).

One of the advantages of working on a first-difference model is to remove the unobserved time-invariant firms, i.e. Fixed Effect (FE). ${ }^{3}$ Thus, a MLRE model can be estimated. In addition, the previous year's productivity change has an impact on the current year's productivity change, e.g. a higher efficiency at $t-1$ makes any further improvement of the current efficiency more difficult (Simar and Wilson, 2007). To address this dynamic, the lagged value of efficiency score in VRS is included in equation \#8.

Furthermore, the estimations of a production function are mainly subject to the simultaneity bias. Our approach however, in estimating productivity changes as a first step, avoids this bias: cyclical effects impact plants' performances (Olley and Pakes, 1996; Levinsohn and Petrin, 2003) and our LPI estimations approximate these cyclical productivity changes. Our dependent variable, in the production function, i.e. $\triangle P C_{i t}$, also includes productivity change due to the economic situation and our final estimation is not subject to simultaneity bias.

\footnotetext{
${ }^{3}$ As LIP is an arithmetic mean index, the first-difference model (equation \#8) can not be used in logarithms.
} 


\section{Data and Variables}

In the first part of this section, we explain how the database was assembled. In the second part, the plant selection is discussed and, finally, the used local variables are detailed.

\subsection{Matching R\&D and Firm Survey}

The study relies on the cross-mapping of two national surveys: the French Annual Company Survey (EAE) produced jointly by the Ministry of Industry and INSEE (the French Central Statistical Office), and the R\&D survey by the French Ministry of Research. The R\&D survey gives information on the R\&D expenditure and $R \& D$ staff and the Company Survey records general information such as sales, added-value, investments, total staff numbers, wages, intermediate inputs, etc. This cross-mapping produced a panel of plants, observed from 2000 to 2002, with their added-value, workforce, wages, physical capital ${ }^{4}$, human capital $^{5}$ and internal R\&D expenditure (IRDE) at plant level as well as at the Company level.

The added-value, workforce, wages and physical capital are observed at time $t$, whereas $R \& D$ and human capital are respectively the combined IRDE and R\&D staff figures for $t-1$ and $t-2$. This procedure accounts for the cumulative feature of R\&D and introduces a lag between the date at which R\&D is carried out and human resources introduced and the date they impact on production. Scherer and Ravenscraft (1982) observe an average of about 4 or 6 years for this temporal lag between $R \& D$ and the increase of the firm profitability. This temporal lag is reduced here to maximise the number of observations. We can consider that this does not significantly affect the results (Hall, et al. 1984), since at the firm level the correlation of $\mathrm{R} \& \mathrm{D}$ across time is very high.

Matching both surveys leads however to the exclusion of several firms carrying out R\&D. Indeed, over the 4500 observations recorded each year in the R\&D survey, 2000 only are also recorded in the Company survey. This is due to several reasons. Firstly, the sectoral scope is different. The Company Survey in our possession neglects services and agriculture. Thus, only industrial firms are considered in this study. Secondly, the Annual Company Survey records only firms having more than 20 employees, whereas the R\&D Survey takes

\footnotetext{
${ }^{4}$ The physical capital variable has been computed as a sum of investments over 7 years (with a depreciation rate of $15 \%$ a year).

${ }^{5}$ The human capital variable is given by the number of $R \& D$ workers (i.e. researchers and engineers).
} 
into account all the firms employing at least one full time researcher, whatever their size. ${ }^{6}$ The database which we have used contains 416 plants $^{7}$, observed over three years, and regrouped according to three aggregated sectors: Extractions (e.g. metal, salt, water, gas, etc.) composed of 147 plants, Manufacturing Industries (MF, e.g. machine constructions) composed of 207 plants and Other Industries (OI, e.g. milk, textile) composed of 62 plants. ${ }^{8}$ These firms represent $12.3 \%$ of French annual R\&D expenditure and $4.5 \%$ of employment in industry.

This cross-mapping provides us with individual data, which is a progress particularly for assessing the geographical dimension of externalities. Indeed, a major problem in most studies in this field comes from the geographical level of observations. The unit is the metropolitan area or county for the United States and the region (NUTS ${ }^{9} 2$ or 3 ) in Europe. By focusing on an aggregated level, these studies are constrained by the administrative segmentation of a geographical scale which is often quite large and fail to quantify the spillovers enjoyed by each of these firms. Indeed they measure inter-agglomeration spillovers, whereas the major facts lie undoubtedly in the relationship between the firm and the agglomeration it belongs to (Lucas, 1988).

Furthermore, the use of plant data allows us to introduce, along with the plant level inputs and local environmental variables, proxies accounting for intra-firm externalities. The inputs provided at the global level of the firm, especially in terms of $R \& D$, are likely to affect the productivity of each distinct plant. If spillovers effects arise within firms, plants that belong to firms carrying out $R \& D$ in their other plants would be more productive. In order to assess this effect, the human capital available in the remainder of the firm is included in the regression.

\subsection{Analysis at Plant level and the problem of location}

The Company survey is conducted both at plant and firm level, allowing an exact localisation. The R\&D survey however is conducted at the firm level and only a break down by department is available (NUTS3). Indeed, each firm has to indicate the share of its R\&D activities carried out in each department. On this basis, the Ministry of Research provides a dataset that recaps $R \& D$ employment and expenditure by firm in each department. Matching

\footnotetext{
${ }^{6}$ We did not include research institutions situated in Corsica or the overseas departments as the analysis of proximity effects upon such was hardly relevant.

${ }^{7}$ Which represent 328 firms.

${ }^{8}$ The zeros in data represent a null investment in R\&D and not missing values (Thompson et al. 1993).

${ }^{9}$ NUTS: Nomenclature of Statistical Territorial Units; NUTS3 concerns units between 150,000 and 800,000 inhabitants.
} 
this database with the Company survey conducted at plant level allows us most of the time to identify a single R\&D plant in each department (in our sample, $72 \%$ of firms are single-plant). Some firms however may own several plants in the same department. In which case, it is impossible to identify the plant(s) in which R\&D is carried out. We have therefore used the following procedure: the $R \& D$ data for each department has been attributed to each plant individually. This has naturally led to an over-estimation of the research efforts made by some of these plants. Nevertheless, this enables us to consider all of the plants.

A second difficulty comes from the level at which data are available. Indeed, some of the data used to estimate our Griliches production function (1979) are only collected at firm level, and are not available for plants (added-value, capital). Now, studying the spatial dimension requires a view at plant level. For this reason the data observed at firm level has been affected to the different plants on the pro-rata basis of the number of workers per plant. We could therefore hardly estimate the model with the variable "labour". The estimated model is thus normalized by labour: Each variable is divided by the number of workers. The dependent variable is then the productivity of labour and the "labour" variable no longer appears in the estimation.

\subsection{Local environment characteristics}

The local industrial features $(\Delta \mathrm{E})$ are measured according to two variables, as follows:

- the number of workers present locally, as a proxy of the labour market size but also of the final demand (W). This variable is expected to reflect positive pecuniary externalities rising from forward-backward linkages within industries and the functioning of the labour market.

- the mean of the number of workers by plants within the same industry and local department (NWPI). This variable may reflect the level of competition between firms.

The local knowledge production intensity is measured by other companies' R\&D expenditure $(\triangle \mathrm{RD}$ in equation \#8). In order to evaluate the impact of distance on knowledge and pecuniary externalities, these variables are measured for two geographic scales. The first 
level is the 'departement' (NUTS 3), the second is given by the first and second order bordering departments. ${ }^{10}$

The sectoral dimension is accounted for by distinguishing the environmental features of the industry to which each plant belongs and the features of all the other industries. The full set of variables used is summarised in table \#1 below, together with the main descriptive statistics.

Table 1. Variable Descriptions

\begin{tabular}{|c|c|c|c|c|c|}
\hline Variables & Description & Mean & Std-error & Min. & Max. \\
\hline$\triangle T F P$ & Estimated by DEA-dependent variable & -0.08 & 0.10 & -0.95 & 0.51 \\
\hline$T E_{t-1}$ & Technical Efficiency in VRS & 0.59 & 0.31 & 0.01 & 1.00 \\
\hline$\Delta H C F_{t-1}$ & Number of R\&D workers in the firm & -0.46 & 0.48 & -2.23 & 0.11 \\
\hline$\triangle N W P I_{t-1}$ & $\begin{array}{c}\text { Number of workers by plants from the same } \\
\text { industry. }\end{array}$ & -0.14 & 22.89 & -534.63 & 100.86 \\
\hline$\triangle N W P I_{n, t-1}$ & $\begin{array}{l}\text { Number of workers by plants from the same } \\
\text { industry in the neighbouring area. }\end{array}$ & 0.04 & 6.05 & -38.65 & 24.20 \\
\hline$\Delta W I_{t-1}$ & $\begin{array}{l}\text { Number of workers in the same industry within } \\
\text { the department. }\end{array}$ & 95.246 & 736.80 & -5842 & 10324 \\
\hline$\Delta W O I_{t-1}$ & $\begin{array}{l}\text { Number of workers from other industries within } \\
\text { the department. }\end{array}$ & 262.64 & 1849.29 & -19112 & 3262 \\
\hline$\Delta W I_{n, t-1}$ & $\begin{array}{c}\text { Number of workers in the same industry in the } \\
\text { neighbouring area. }\end{array}$ & 759.77 & 3051.32 & -8076 & 27726 \\
\hline$\triangle W O I_{n, t-1}$ & $\begin{array}{c}\text { Number of workers from other industries in the } \\
\text { neighbouring area. }\end{array}$ & 2027.20 & 5373.93 & -29432 & 13022 \\
\hline$\triangle W R D I_{t-1}$ & $\begin{array}{l}\text { R\&D expenditure in the same industry within } \\
\text { the department. }\end{array}$ & 31139.17 & 213228.69 & -1268554.96 & 2178857.59 \\
\hline$\Delta W D O I_{t-1}$ & $\begin{array}{l}\text { R\&D expenditure in other industries within the } \\
\text { department. }\end{array}$ & 285961.05 & 661008.15 & -1660914.19 & 4066033.19 \\
\hline$\Delta W R D I_{n, t-1}$ & $\begin{array}{c}\text { R\&D expenditure in the same industry in the } \\
\text { neighbouring areas. }\end{array}$ & 93316.47 & 392205.43 & -1645006.08 & 3075880.59 \\
\hline$\triangle W R D O I_{n, t-1}$ & $\begin{array}{c}\text { R\&D expenditure from other industries in the } \\
\text { neighbouring areas. }\end{array}$ & 2273715.96 & 1706815.08 & -1102542.26 & 6743609.92 \\
\hline
\end{tabular}

\footnotetext{
${ }^{10}$ the contiguity matrix is standardized in row.
} 


\section{Results}

In this section, the results of the DEA approach are presented first and those from the MLRE model, second.

\subsection{Productivity analysis}

Table \# 2 presents the arithmetic means of the LPI (Balk, 1998) estimated under the VRS assumption. $^{11}$

Table 2. LPI Results

\begin{tabular}{|c|c|c|c|c|c|c|c|}
\hline Sectors & $\Delta$ PE & $\Delta$ SE & $\Delta$ EF & $\Delta$ IB & $\Delta$ MT & $\Delta$ TECH & $\Delta$ TFP \\
\hline \multicolumn{7}{|c|}{$\mathbf{2 0 0 0 - 2 0 0 1}$} \\
\hline Other Industries & 0.009 & -0.004 & $\mathbf{0 . 0 0 5}$ & -0.092 & -0.021 & $\mathbf{- 0 . 1 1 3}$ & $\mathbf{- 0 . 1 0 8}$ \\
\hline Manufacturing & 0.021 & -0.004 & $\mathbf{0 . 0 1 7}$ & -0.086 & -0.026 & $\mathbf{- 0 . 1 1 2}$ & $\mathbf{- 0 . 0 9 5}$ \\
\hline Extractions & -0.016 & 0.007 & $\mathbf{- 0 . 0 0 9}$ & -0.058 & -0.012 & $\mathbf{- 0 . 0 7 0}$ & $\mathbf{- 0 . 0 7 9}$ \\
\hline Mean & 0.006 & $8.10^{\mathrm{e}(-5)}$ & $\mathbf{0 . 0 0 6}$ & -0.077 & -0.021 & $\mathbf{- 0 . 0 9 8}$ & $\mathbf{- 0 . 0 9 2}$ \\
\hline \multicolumn{7}{|c|}{$\mathbf{2 0 0 1 - 2 0 0 2}$} \\
\hline Other Industries & 0.022 & -0.021 & $\mathbf{0 . 0 0 1}$ & -0.027 & -0.008 & $\mathbf{- 0 . 0 3 5}$ & $\mathbf{- 0 . 0 3 4}$ \\
\hline Manufacturing & -0.045 & 0.022 & $\mathbf{- 0 . 0 2 3}$ & -0.035 & -0.007 & $\mathbf{- 0 . 0 4 2}$ & $\mathbf{- 0 . 0 6 5}$ \\
\hline Extractions & -0.014 & 0.002 & $\mathbf{- 0 . 0 1 2}$ & -0.053 & -0.008 & $\mathbf{- 0 . 0 6 2}$ & $\mathbf{- 0 . 0 7 4}$ \\
\hline Mean & -0.023 & 0.008 & $\mathbf{- 0 . 0 1 5}$ & -0.040 & -0.008 & $\mathbf{- 0 . 0 4 8}$ & $\mathbf{- 0 . 0 6 3}$ \\
\hline
\end{tabular}

A first examination of table \#2 shows a large decrease of the firms' productivity between 2000 and 2001 which then levels out over 2001-2002. The LPI, for example, indicates that, on average and when compared to the whole of the industries resources, manufacturing should have simultaneously contracted its inputs and increased its output by 9.5\% in order to achieve a stable productivity. These results are in accordance with statistical insights on French labour market (see INSEE): product demand seriously decreases from the middle of 2000 until 2002 with a slight improvement at the end of 2002. Furthermore, a large decrease in the employed labour force and of the rate of use of each firm productive capacity is perceived over the same period. ${ }^{12}$ Thus, the better scores in 2001-2002 are mainly due to a

\footnotetext{
${ }^{11}$ Following the section $\# 3.1, \Delta \mathrm{TFP}=\Delta \mathrm{TECH}+\Delta \mathrm{EF}, \triangle \mathrm{EF}=\Delta \mathrm{PE}+\triangle \mathrm{SE}$ and $\triangle \mathrm{TECH}=\Delta \mathrm{IB}+\Delta \mathrm{MAT}$.

${ }^{12}$ See statistics of the French labour ministry.
} 
slight improvement of the economic situation and a better management of plant resources, with input decreases (see table \#4 in appendix). ${ }^{13}$

For the first period, extraction industries improve their inputs whereas their added values decrease. Therefore, $\triangle \mathrm{EF}$ and $\triangle \mathrm{TECH}$ present negative signs. In the second period, extraction industries decrease their inputs but insufficiently. Nevertheless, these input decreases have a positive effect on technological component when compared to the first period. Thus, $\triangle \mathrm{TECH}$ can be interpreted as machine closures ${ }^{14}-$ or decreases in the number of workers - in the plant (another inefficiency form, Milana et al. 2008) whereas $\triangle \mathrm{EF}$ typically refers to the efficiency of the currently used inputs. Our interpretation is in conformity with the results for the other industries. For the Other Industries, input increases are larger than output growth for the two periods. Therefore, in order to compensate for the negative effects of the technological gap, efficiency of the used resources increases. Concerning manufacturing industries, input decreases, over the first period, are larger than the output decrease, implying a positive sign for $\triangle \mathrm{EF}$ and a negative sign for $\triangle \mathrm{TECH}$. By contrast over the second period, input decreases are not sufficient compared to those of the output, i.e. negative signs of $\triangle \mathrm{EF}$ and only a slight increase of $\triangle \mathrm{TECH}$.

Furthermore, $\triangle \mathrm{EF}$ can be broken down into Pure Efficiency (PE) and Scale Effects (SE). Efficiency variations are mainly driven by $\triangle \mathrm{PE}$ instead of $\triangle \mathrm{SE}$. In accordance with $\triangle \mathrm{TECH}$ results, there are insufficient positive variations of technological component to reach significant scale effects. Thus, plants have no choice other than to increase or decrease the use of their inputs according to the economic situation (i.e. PE). Nevertheless, positive SE is found on the mean and, according to O'Mahonny and Vecchi (2009), this factor should grow with increasing investment in R\&D capital.

As TFP change is mainly driven by the technological component, it will be interesting to investigate technological variations in detail. For this purpose, technological decomposition is used (see section \#3.1). In particular, a large negative change of "biased input" ( $\Delta I B)$ is found. In other words, some of the inputs yield weaker relative contributions to the output than others. Nevertheless, a significant part of the variation of $\triangle \mathrm{TECH}$ is due, for the first period, to a proportional diminishing of the input set (see $\Delta \mathrm{MT}$ ). From a statistical viewpoint,

\footnotetext{
${ }^{13}$ Showing a better adaptation of firms to the economic situation.

${ }^{14}$ Additionally, changes in the use of machines - for example, an increase - must always be compared in respect to the output change in order to assess the sign of the technological component.
} 
the labour force is rising while the output is decreasing over the same period (e.g. growth of $28 \%$ of wage mean in Other Industries). Therefore, this input has a weaker relative contribution to the output in 2000-2001. This result is in conformity with technological variations as the worker's skills are less used. In the second period, firms better anticipated the unfavourable economic situation and they have decreased their total inputs. Nevertheless, firms have chosen not to decrease their inputs in the same way - or in the same proportionality - as $\Delta \mathrm{IB}$ shows large negative coefficients. Statistically, firms have chosen to decrease their investments in $R \& D$ in view of the decreasing demand (e.g. $-22.6 \%$ in manufacturing industries). Due to this similar trend of both output and $R \& D$, the influence of $R \& D$ on the output is more difficult to evaluate. Nevertheless, as the returns on $R \& D$ investments are more uncertain and take longer to become visible, the $R \& D$ contribution to the output is perceived by employers as less significant in an unfavourable economic situation.

\subsection{Econometric Results}

An initial examination of the results ${ }^{15}$ presented in table \#3 confirms the correlation assumption between efficiency at $t-1$ and current TFP: a higher lagged efficiency score has a large negative impact on the current TFP change. The higher the efficiency of a plant, the more difficult it is to continue to approach the production frontier (Boussemart et al. 2006). Even though the literature on agglomeration forces focuses on inter-firm effects, intra-firms spillovers are also highly significant: human capital proxy of the firms is a major determinant of their productivity. In particular, this intra-firm effect greatly improves the technological component and decreases, by opposition, the efficiency of the used inputs. This result supports some previous results concerning increasing returns associated with organizational and geographical linkages among various functions of the firms. Kenney and Florida (1994) point out that "transfer of employees between $R \& D$ and manufacturing and joint meetings are judged as being the most important factors in ensuring the information transfer between the two corporate functions." In addition, the close location of $\mathrm{R} \& \mathrm{D}$ units and production units would insure better knowledge creation and information transfer. Furthermore, the technological decomposition shows that human capital homogeneously increases the relative

\footnotetext{
${ }^{15}$ To improve the readability of this table each estimated coefficients have been multiplied by $10^{6}$.
} 
contribution of each input. In other words, human capital increases also the efficiency of capital and, obviously, the R\&D component.

Concerning the inter-firm effects and, more specifically, $R \& D$ investments within the same industry in the department, the estimated coefficient presents the expected signs: plants receive positive spillovers from the $R \& D$ investments of other plants which obviously improve the technological component. $R \& D$ investments of the other industries in the department however have no significant spillovers on the plant in question. This result supports Marshall-Arrow-Romer externalities more than Jacobs externalities. It differs from empirical evidence drawn from the French case using regional patent data as dependent variable (Autant-Bernard and LeSage, 2009). Based on a knowledge production function, Feldman and Audretsch (1999) found - in contrast with our result - that diversity would pay a positive role on innovative firms, while more traditional activities would primarily benefit from specialisation. Since only R\&D firms are considered in this study, one would expect a positive impact of diversity. Therefore, moving from a spatial knowledge production function to a TFP function gives different results. This point would however deserve further attention and could be addressed in further research.

For the local workers variables, the results may capture two opposite effects: first, a positive effect of agglomeration spillovers, second, a pure productivity effect which implies that a higher number of workers in the area, in an unfavourable economic situation, decreases the productivity. Thus, the negative effects registered for worker variables show that negative productivity effects exceed those positive from agglomeration. Furthermore, places which favour a high employment rate are generally low-tech areas, ${ }^{16}$ explaining our negative impact upon technological component by opposition to the results of the WRDI variable which represents probably the high-tech areas. Then, higher positive externalities in "high-tech" places (in comparison to the "low-tech" places) are found. By contrast, the number of workers of the industries in the neighbouring area slightly improves a plant's efficiency which could be due to worker exchanges. Following the efficiency decomposition, this improvement of the workers' efficiency (i.e. PE) decreases $\Delta$ SE. Furthermore, some relative input contributions change in a "non neutral" way, in particular the one of labour force. ${ }^{17}$

\footnotetext{
${ }^{16}$ Since our microeconomic data are essentially composed of manufacturing industries (Diaz and Quiros Tomas, 2002).

${ }^{17}$ Estimations of the dependent variables - $\triangle \mathrm{PE}$ and $\triangle \mathrm{MT}$ - have been dropped, since they have respectively the opposite signs of $\Delta \mathrm{SE}$ and $\Delta \mathrm{IB}$.
} 
Table 3. Spillover Estimations by MLRE

\begin{tabular}{|c|c|c|c|c|c|}
\hline Variables & $\Delta$ TFP & $\triangle \mathrm{TECH}$ & $\Delta \mathbf{E F}$ & $\Delta \mathbf{S E}$ & $\Delta \mathrm{IB}$ \\
\hline \multicolumn{6}{|c|}{ Plant and Firm Features } \\
\hline$T E_{t-1}$ & $\begin{array}{c}-39103.50 * * * \\
(8070.30)\end{array}$ & $\begin{array}{l}-10418.30 \\
(7228.20)\end{array}$ & $\begin{array}{c}-28685.20 * * * \\
(4638.50)\end{array}$ & $\begin{array}{c}35092.40 * * * \\
(5062.80)\end{array}$ & $\begin{array}{c}-63777.60 * * * \\
(8429.10)\end{array}$ \\
\hline$\Delta H C F_{t-1}$ & $\begin{array}{c}40844.80 * * * \\
(6235.20)\end{array}$ & $\begin{array}{c}62015.00 * * * \\
(5584.60)\end{array}$ & $\begin{array}{c}-21170.20 * * * \\
(3583.80)\end{array}$ & $\begin{array}{c}10554.20 * * \\
(3911.60)\end{array}$ & $\begin{array}{c}-31724.40 * * * \\
(6512.40)\end{array}$ \\
\hline \multicolumn{6}{|c|}{ Local Features } \\
\hline$\Delta W R D I_{t-1}$ & $\begin{array}{l}0.04 * * \\
(0.01)\end{array}$ & $\begin{array}{l}0.03^{*} \\
(0.01)\end{array}$ & $\begin{array}{c}0.01 \\
(0.01)\end{array}$ & $\begin{array}{l}-0.01 \\
(0.01)\end{array}$ & $\begin{array}{l}0.02 \\
(0.02)\end{array}$ \\
\hline$\Delta W R D O I_{t-1}$ & $\begin{array}{c}-0.01 \\
(0.005)\end{array}$ & $\begin{array}{l}-0.005 \\
(0.004)\end{array}$ & $\begin{array}{l}-0.002 \\
(0.003)\end{array}$ & $\begin{array}{l}-0.002 \\
(0.003)\end{array}$ & $\begin{array}{l}-0.001 \\
(0.005)\end{array}$ \\
\hline$\Delta W I_{t-1}$ & $\begin{array}{c}-10.70^{*} \\
(4.97)\end{array}$ & $\begin{array}{c}-10.80 * \\
(4.45)\end{array}$ & $\begin{array}{c}0.15 \\
(2.86)\end{array}$ & $\begin{array}{c}0.23 \\
(3.12)\end{array}$ & $\begin{array}{l}-0.08 \\
(5.20)\end{array}$ \\
\hline$\Delta W O I_{t-1}$ & $\begin{array}{c}-6.13 * * \\
(1.91)\end{array}$ & $\begin{array}{c}-6.99 * * * \\
(1.71)\end{array}$ & $\begin{array}{c}0.86 \\
(1.10)\end{array}$ & $\begin{array}{l}-0.16 \\
(1.20)\end{array}$ & $\begin{array}{c}1.02 \\
(1.99)\end{array}$ \\
\hline$\Delta N W P I_{t-1}$ & $\begin{array}{c}-11.80 \\
(145.10)\end{array}$ & $\begin{array}{c}10.40 \\
(12.99)\end{array}$ & $\begin{array}{l}-22.20 \\
(83.40)\end{array}$ & $\begin{array}{c}32.30 \\
(91.00)\end{array}$ & $\begin{array}{c}-54.50 \\
(151.50)\end{array}$ \\
\hline \multicolumn{6}{|c|}{ Spatially Lagged Local Features } \\
\hline$\triangle W R D I_{n, t-1}$ & $\begin{array}{l}-0.01 \\
(0.01)\end{array}$ & $\begin{array}{l}-0.02 * \\
(0.007)\end{array}$ & $\begin{array}{c}0.003 \\
(0.005)\end{array}$ & $\begin{array}{l}-0.001 \\
(0.005)\end{array}$ & $\begin{array}{l}0.004 \\
(0.01)\end{array}$ \\
\hline$\Delta W R D O I_{n, t-1}$ & $\begin{array}{c}-0.01 * * * \\
(0.002)\end{array}$ & $\begin{array}{c}-0.01 * * * \\
(0.001)\end{array}$ & $\begin{array}{l}0.0002 \\
(0.001)\end{array}$ & $\begin{array}{l}-0.002 * \\
(0.001)\end{array}$ & $\begin{array}{c}0.003 \\
(0.002)\end{array}$ \\
\hline$\Delta W I_{n, t-1}$ & $\begin{array}{c}0.44 \\
(1.41)\end{array}$ & $\begin{array}{l}-1.96 \\
(1.27)\end{array}$ & $\begin{array}{l}2.41 * * \\
(0.81)\end{array}$ & $\begin{array}{c}-3.98 * * * \\
(0.89)\end{array}$ & $\begin{array}{c}6.38 * * * \\
(1.48)\end{array}$ \\
\hline$\Delta W O I_{n, t-1}$ & $\begin{array}{l}-1.70^{*} \\
(0.68)\end{array}$ & $\begin{array}{l}-1.47^{*} \\
(0.61)\end{array}$ & $\begin{array}{l}-0.23 \\
(0.39)\end{array}$ & $\begin{array}{l}-0.68 \\
(0.43)\end{array}$ & $\begin{array}{l}0.44 \\
(0.71)\end{array}$ \\
\hline$\Delta N W P I_{n, t-1}$ & $\begin{array}{l}906.90 \\
(620.90)\end{array}$ & $\begin{array}{c}308.90 \\
(556.10)\end{array}$ & $\begin{array}{c}598.10 \\
(356.80)\end{array}$ & $\begin{array}{c}114.50 \\
(389.50)\end{array}$ & $\begin{array}{l}483.60 \\
(648.50)\end{array}$ \\
\hline Log-Likelihood & 802.79 & 894.37 & 1262.99 & 1190.27 & 766.65 \\
\hline
\end{tabular}

Note: * Significant at the 10\% level, ** significant at the 5\% level, *** significant at the $1 \%$ level.

In addition, $R \& D$ investments in the neighbouring area seem to have a negative impact on TFP changes. These results can be explained by a "shadow effect" (Autant-Bernard, 2001b): high industrial clustering, in the neighbouring area, captures R\&D investments and consequently has a negative impact on the TFP of the considered plant. Hence, this unfavourable effect is due to the negative impact of technological change - which represents the fall in R\&D investments - with negative estimated coefficients for $W R D I_{n}$ and $W R D O I_{n}$ 
variables. Furthermore, this lack in R\&D attractivity due to "shadow effects" decreases the $\triangle \mathrm{SE}$ component.

Finally, the number of workers by plants in the neighbouring and local area has no significant effect. This result is not surprising since the expected positive impact of economic competition upon productivity is lower (due to higher financial pressure) during an unfavourable economic situation (Nickell et al. 1997).

\section{Conclusion}

The results from our study can help us to paint a picture of policy recommendations. The main result is that intra-firm spillovers across multiple locations have stronger influence than inter-firm spillovers: the proxy of the human capital of the company largely and homogeneously improves the technological component of the productivity and increases scale effects. Improving knowledge flows within firms would generate more benefits than spillovers stemming from outside the firm. This opens up an interesting area of research, in order to better understand the role played by distance on this intra-firm knowledge flows. These intra-firm externalities can give rise to spatial concentration phenomena. Economies of localisation and urbanisation due to inter-firms spillovers would no longer be the only determinant of agglomeration. This latter would also partly result from the internal strategies of the firms: close proximity between the different plants of a single firm in order to reduce the transport and transaction costs. Our empirical approach however, does not allow us to address this question directly. Further analysis of the role played by distance on these intrafirm knowledge flows would be required.

Nevertheless, some significant inter-firm effects are found: (i) benefits from the R\&D of the other firms within the same industry in the region for the technology used, (ii) "shadow effects" which decrease the technological component, when a plant is established near an industrial clustering, and prevent plants' scale economies. Nevertheless, spillover intensities must be discussed with caution as our estimations are based on a period during an unfavourable economic situation.

For a given human capital of a firm, a feasible recommendation would be: in an unfavourable economic situation, plants should be inside industrial clusters in order to benefit from the knowledge externalities and avoid the "shadow effect" when locating outside. This picture would improve the efficiency of plants and confirm the currently observed behaviour: at national level, local-clustering is reinforced (Cantwell and Vertova, 2004). 
Additional studies are required to confirm our results: in particular, a comparison of the spillover intensities and the role of economic competition between favourable and unfavourable economic situations would be an interesting angle. Such a framework however still remains to be envisaged.

\section{Appendix}

Table 4. Descriptive Statistics by Industries

\begin{tabular}{|c|c|c|c|c|c|c|}
\hline Variables & $\begin{array}{c}\text { Extraction } \\
\text { Mean }\end{array}$ & $\begin{array}{c}\text { Extraction } \\
\text { Std }\end{array}$ & $\begin{array}{c}\text { Other } \\
\text { Industries } \\
\text { Mean }\end{array}$ & $\begin{array}{c}\text { Other } \\
\text { industries } \\
\text { Std }\end{array}$ & $\begin{array}{c}\text { Manufacturing } \\
\text { Mean }\end{array}$ & $\begin{array}{c}\text { Manufacturing } \\
\text { Std }\end{array}$ \\
\hline \multicolumn{7}{|c|}{2000} \\
\hline$A V$ & 691.74 & 379.39 & 369.66 & 119.40 & 426.97 & 179.78 \\
\hline$W M$ & 227.55 & 81.13 & 176.51 & 53.55 & 201.09 & 62.09 \\
\hline$H C$ & 0.12 & 0.32 & 0.04 & 0.08 & 0.19 & 0.67 \\
\hline$R D I$ & 218.82 & 557 & 82.17 & 312.72 & 387.47 & 1770.45 \\
\hline$K$ & 337.11 & 410.06 & 117.37 & 161.08 & 207.42 & 830.52 \\
\hline \multicolumn{7}{|c|}{2001} \\
\hline$A V$ & 670.59 & 403.15 & 376.58 & 139.39 & 424.39 & 190.43 \\
\hline$W M$ & 230.81 & 77.12 & 225.90 & 282.52 & 199.71 & 59.11 \\
\hline$H C$ & 0.13 & 0.30 & 0.04 & 0.11 & 0.19 & 0.73 \\
\hline$R D I$ & 224.46 & 533.59 & 86.36 & 324.45 & 369.96 & 1742.72 \\
\hline $\bar{K}$ & 415.25 & 779.29 & 135.90 & 181.84 & 196.26 & 640.52 \\
\hline \multicolumn{7}{|c|}{2002} \\
\hline$A V$ & 665.56 & 442.70 & 381.11 & 149.47 & 410.83 & 154.56 \\
\hline$W M$ & 224.42 & 71.27 & 193.98 & 63.03 & 204.52 & 58.25 \\
\hline$H C$ & 0.12 & 0.28 & 0.06 & 0.17 & 0.16 & 0.48 \\
\hline$R D I$ & 221.46 & 520.69 & 101.57 & 325.50 & 301.68 & 1339.65 \\
\hline$K$ & 383.19 & 458.62 & 193.06 & 383.02 & 187.70 & 338.51 \\
\hline
\end{tabular}




\section{References}

Acs, Z.J., Audretsch, D.B., Feldman, M.P., 1991. Real Effects of Academic Research: Comment. American Economic Review 82, 363-67.

Arrow, K.J., 1962. Economic Welfare and the Allocation of Resources of invention. in Nelson R.R. (ed.), The Rate and Direction of Inventive Activity: Economic and Social Factors, Princeton University Press, 609-26.

Audretsch, D.B., Feldman, M.P., 1999. Innovation in Cities: Science-Based Diversity, Specialization and Localized Competition. European Economic Review 43, 409-29.

Autant-Bernard, C., 2001a. The Geography of Knowledge Spillovers and Technological Proximity. Economics of Innovation and New Technology 10, 237-54.

Autant-Bernard, C., 2001b. Science and Knowledge Flows: Evidence from the French Case. Research Policy 30, 1069-78.

Autant-Bernard, C., LeSage, J., 2009. Quantifying Knowledge Spillovers using Spatial Econometric Models. CORE seminar, Catholic University of Louvain, 13 may.

Balk, B.M., 1998. Industrial Prices, Quantity, and Productivity Indices: The Micro-Economic Theory and an Application. Kluwer, Boston.

Barros, C.P., Peypoch, N., 2008. A Comparative Analysis of Productivity Change in Italian and Portuguese Airports. International Journal of Transport Economics 35, 243-54.

Black, S.E., Lynch, L.M., 2001. How to Compete: The Impact of Workplace Practices and information Technology on Productivity. Review of Economics and Statistics 83, 43445 .

Beaudry, C., Breschi, S., 2003. Are Firms in Clusters Really more Innovative?. Economics of Innovation and New Technology 12, 325-42.

Bottazzi, L., Peri, G., 2003. Innovation and Spillovers in Regions: Evidence from European Patent Data. European Economic Review 47, 687-710.

Boussemart, J-P., Briec, W., Cadoret, I., Tavéra, C., 2006. A Re-Examination of the Technological Catching-Up Hypothesis across OECD Industries. Economic Modelling 23, 967-77.

Briec, W., 1997. A Graph Type Extension of Farrell Technical Efficiency Measure. Journal of Productivity Analysis 8, 95-110.

Briec, W., Chambers, R.G., Färe, R., Peypoch, N., 2006. Parallel Neutrality. Journal of Economics 88, 285-305.

Briec, W., Comes, C., Kerstens, K. 2006. Temporal Technical and Profit Efficiency Measurement: Definitions, Duality and Aggregation Results. International Journal of Production Economics 103, 48-63.

Briec, W., Peypoch, N., 2007. Biased Technical Change and Parallel Neutrality. Journal of Economics 92, 281-92.

Cantwell, J., Vertova, G., 2004. Historical Evolution of Technological Diversification. Research Policy 33, 511-29. 
Chambers, R.G., 1996. A New Look at Exact Input, Output, and Productivity Measurement. Working Paper 05, Department of Agricultural and Resources Economics, University of Maryland.

Chambers, R.G., Chung, Y., Färe, R., 1998. Profit, Directional Distance Functions, and Nerlovian Efficiency. Journal of Optimization Theory and Applications 98, 351-64.

Chambers, R.G., Färe, R., Grosskopf, S., 1996. Productivity Growth in APEC Countries. Pacific Economic Review 1, 181-90.

Cohen, W., Levinthal, D.A., 1989. Innovation and Learning: The Two Faces of R\&D. Economic Journal 99, 569-96.

Diaz, M.S., Quiros Tomas, F.J., 2002. Technological Innovation and Employment: Data from a Decade in Spain. International Journal of Production Economics 75, 245-56.

Färe, R., Grosskopf, S., Norris, M., Zhang, Z., 1994. Productivity Growth, Technical Progress, and Efficiency Change in Industrialized Countries. American Economic Review 84, 66-83.

Feldman, M.P., Audretsch, D.B., 1999. Innovation and Cities: Science-based Diversity, Specialization, and Localized Competition. European Economic Review 43, 409-29.

Guironnet, JP., Peypoch, N., 2007. Human Capital Allocation and Overeducation: A Measure of French Productivity $(1987,1999)$. Economic Modelling 24, 398-410.

Griliches, Z., 1979. Issues in Assessing the Contribution of Research and Development to Productivity Growth. Bell Journal of Economics 10, 92-116.

Hausman, J., Hall, B., Griliches, Z., 1984. Economic Models for Count Data with an Application to the Patents R\&D Relationship. Econometrica 52, 909-38.

Henderson, J.V., 2003. Marshal's Scale Economies. Journal of Urban Economy 53, 1-28.

Henderson, J.V., Kuncoro, A., Turner, M., 1995. Industrial Development in Cities. Journal of Political Economy 103, 1067-90.

Jacobs, J., 1969. The Economies of Cities. Random House.

Jaffe, A.B., 1986. Technology Opportunity and Spillovers of R\&D: Evidence from Firms' Patents, Profits, Market Value. American Economic Review 76, 984-1001.

Jaffe, A.B.Trajtenberg, M., Henderson, R., 1993. Geographic Localization of Knowledge Spillovers as Evidenced by Patent Citation. Quarterly Journal of Economics 108, 57798.

Kenney, M., Florida, R., 1994. The organization and geography of Japanese R\&D: results from a survey of Japanese electronics and biotechnology firms. Research Policy 23, 305-23.

Levinsohn, J., Petrin, A., 2003. Estimating Production Functions Using Inputs to Control for Unobservables. Review of Economic Studies 70, 317-42.

Lucas, R.E., 1988. On the Mechanics of Economic Development. Journal of Monetary Economics 22, 3-42.

Luenberger, D.G., 1996. Welfare from a Benefit Viewpoint. Economic Theory 7, 445-62.

Jena, P.R., Managi, S., 2008. Environmental Productivity and Kuznets Curve in India. Ecological Economics, 432-40.

Marshall, A., 1980. Principles of Economics. Macmillan, London. 
Martin, P., Ottaviano, G., 1999. Growing Location: Industry Location in a Model of Endogenous Growth. European Economic Review 43, 281-302.

Milana, C., Leopoldo, N., Zeli, A., 2008. Changes in Multifactor Productivity in Italy from 1998-2004: Evidence from Firm-Level Data Using DEA. Working Paper 33, EU Klems.

Nakano, M., Managi, S., 2008. Regulatory Reforms and Productivity: An Empirical Analysis of the Japanese Electricity Industry. Energy Policy 36, 201-9.

Nickell, S., Nicolitsas, D., Dryden, N., 1997. What Makes Firms Perform Well?. European Economic Review 41, 783-96.

Olley, G.S., Pakes, A., 1996. The Dynamics of Productivity in the Telecommunications Equipment Industry. Econometrica 64, 1263-98.

O’Mahony, M., Vecchi, M., 2009. R\&D, Knowledge Spillovers and Company Productivity Performance. Research Policy 38, 35-44.

Ravenscraft, D., Scherer, F.M., 1982. The Lag Structure of Returns to Research and Development. Applied Economics 14, 603-20.

Romer, P., 1986. Increasing Returns and Long Run Growth. Journal of Political Economy 94, 1002-37.

Simar, L., Wilson, P.W., 2007. Estimation and Inference in Two-Stage, Semi-Parametric Models of Production Processes. Journal of Econometrics 136, 31-64.

Thompson, R.G., Dharmapala, P.S., Thrall, R.M., 1993. Importance for DEA of Zeros in Data Multipliers, and Solutions. Journal of Productivity Analysis 4, 379-90.

Wooldridge, J.M., 1995. Selection Corrections for Panel Data Models under Conditional Mean Independence Assumptions. Journal of Econometrics 68, 115-32.

Yang, C-H., Motohashi, K., Chen, J-R., 2009. Are New Technology-Based Firms Located on Science Parks Really more Innovative? Evidence from Taiwan. Research Policy 38, 7785.

Zhengfei, G., Oude Lansink, A., 2006. The Source of Productivity Growth in Dutch Agriculture: A Perspective from Finance. American Journal of Agricultural Economics 88, 644-56. 